\title{
Effects of Tillage Systems in Durum Wheat under Rainfed Mediterranean Conditions
}

\author{
S.A. Colecchia, P. De Vita and M. Rinaldi* \\ Agricultural Research Council, Cereal Research Centre, S.S. 673, km 25,200, 71122 Foggia, Italy
}

(Received 23 September 2014; Accepted 16 January 2015)

\begin{abstract}
A 2-year conservation agriculture experiment was conducted in Southern Italy on durum wheat continuous cropping. Aim of the research was to assess the durum wheat productivity and grain quality in reduced soil tillage systems, according to conservation agriculture principles. The interactions among experimental treatments and climate revealed a close relationship among grain yield, grain quality and wheat growth conditions. Specifically, conventional tillage (CT, plowing and 2 disc harrowing) showed in the 2-year period higher grain production than reduced tillage treatments, minimum (MT, 1 disc harrowing) and No tillage (NT), especially for good crop water availability $\left(3.29 \mathrm{t} \mathrm{ha}^{-1}\right.$ of grain yield in CT, 2.67 in MT and 2.54 in NT). The amount of rainfall (above the average in both years) and its distribution in the growing seasons (more regular in the first year) strongly influenced wheat-grain quality indices ( $11.97 \%$ of protein content in the first year and $9.82 \%$ in the second one). Also, the wheat quality resulted more sensitive to the "Year $\times$ Tillage" interaction, with differences among tillages more evident in the second year and favourable to NT and MT. Spectral vegetation indexes (NDVI and TVI) measurements at flowering, have been shown to be useful to support farmers in N-late application for improving grain wheat quality. From this experiment carried out during the conversion period and in wet years, wheat managed with CT resulted in higher grain yield and quality, while only test weight showed a significant "Year $\times$ Tillage" interaction. Further indications emerged on the need to supply additional (10-20\%) seed amount at sowing and crop nitrogen fertilizer in the first transition years in reduced tillage systems compared to conventional ones.
\end{abstract}

Keywords: conservation agriculture, tillage, grain yield, grain quality, protein, vegetation index

\section{Introduction}

"Conservation Agriculture (CA) is an approach to manage agro-ecosystems for improved and sustained productivity, increased profits and food security while preserving and enhancing the resource base and the environment. CA is characterized by three linked principles, namely: i) continuous minimum mechanical soil disturbance; ii) permanent organic soil cover; iii) diversification of crop species grown in sequences and/or associations" (FAO 2011). The main objective of CA is to protect the soil environment against

\footnotetext{
* Corresponding author; E-mail: michele.rinaldi@entecra.it
} 
degradation and to create optimal conditions for plant productivity. Minimum and/or no tillage systems with the simultaneous application of mulch can create such conditions. The application of no-till systems improves soil physical properties (Tebrügge and Düring 1999) and increases soil water content in rainfed conditions in Southern Europe (De Vita et al. 2007). This ensues from an increased organic matter content in the soil (Micucci and Taboada 2006) and a reduced rate of soil infiltration (Lipiec et al. 2006), which in effect leads to increased soil water content (Lampurlanés and Cantero-Martínez 2006).

Winter cereal crops response to CA practices is variable (Rao and Dao 1996). Higher yield is usually attributed to increased water conservation, especially in arid and semiarid regions; whereas lower yield is attributed to greater disease and weed infestations and $\mathrm{N}$ immobilization (Lopez-Bellido et al. 1996; McMaster et al. 2002; Ozpinar 2006). Crop yields immediately after no-till conversion period are often appreciably lower than after ploughing but improve after about three years of no-till as soil structural conditions improve (Six et al. 2004; Anken et al. 2006).

Durum wheat (Triticum durum Desf.) grain quality is ranked according to the grain protein concentration. This is largely dependent on genotype (Johnson et al. 1985; Stoddard and Marshall 1990; Colecchia et al. 2012), but is also influenced by the complex interactions between nitrogen $(\mathrm{N})$ and water availability, yield and temperature (Randall and Moss 1990; Cox and Shelton 1992; Troccoli et al. 2000; Di Fonzo et al. 2001; LopezBellido and Lopez-Bellido, 2001; Flagella 2006).

The experimental evidences about wheat quality as function of soil tillage are contrasting and site-specific: Carr et al. (2003) reported in a sandy loam soil in Great Plain (USA) that protein content, single kernel weight and test weight were unaffected by tillage systems, while Di Fonzo et al. (2001) and De Vita et al. (2007) in the same experimental farm in Southern Italy found higher protein content, single kernel weight and test weight for no-till than for CT management. In contrast, in rainfed Southern Spain, Lopez-Bellido et al. $(1998 ; 2001)$ reported higher protein content under conventional tillage than no-till. Also, in another study, protein content and sedimentation value decreased slightly without tillage when compared to a tillage based system in silty loam soil in South Germany (Pringas and Koch 2004).

Wheat yield and protein content are negatively and linearly related: the most frequently quoted reasons for this are energy constraints and dilution effects. Under favourable growing conditions, starch and protein build up simultaneously and protein content may vary by $\pm 2 \%$ (Pearman et al. 1978; Halloran 1981). Water stress and high temperature during the grain-filling period hinder the conversion of sucrose into starch but have less effect on protein formation (Brooks et al. 1982; Bhullar and Jenner 1986). Tillage method may also influence the protein content and breadmaking quality of wheat modifying organic $\mathrm{N}$ mineralization rate, distribution in soil profile and availability for the crop (Borghi et al. 1995; Trethowan et al. 2012; Sip et al. 2013). Soil $\mathrm{N}$ availability greatly influences grain $\mathrm{N}$ content and quality: the evaluation of a remote/proximal sensing system (i.e. use of spectral reflectance) to early detect $\mathrm{N}$ plant deficiency, also in the perspective of a late $\mathrm{N}$ application, has been carried out by means of vegetation indices with promising results (Mulla 2013). 
The aim of the paper was to assess the effect of conservation agriculture systems, compared to conventional tillage, on durum wheat productivity and quality under rainfed conditions of a Mediterranean climate environment and during the conversion period.

\section{Materials and Methods}

\section{Experimental design and crop management}

Field experiment was conducted at Foggia, Southern Italy, in the experimental farm of Agricultural Research Council - Cereal Research Centre (41 ${ }^{\circ} 27^{\prime} \mathrm{N}, 15^{\circ} 36^{\prime} \mathrm{E}-90 \mathrm{~m}$ above sea level) on a Vertisol Typic Haploxerert (USDA classification) typical of the Mediterranean region, classified as clay-loam. The main physical and chemical characteristics are reported in Table $\mathrm{S} 1 *$.

The experiment was carried out in 2007/08 and 2008/09. In the previous year (2006/07, durum wheat as preceeding crop) the same soil tillage was used (deep chisel $70 \mathrm{~cm}$ depth and one pass with disc harrowing) in all the $10,000 \mathrm{~m}^{2}$ field area, in order to standardize soil conditions. The experimental design was a Randomized Block Design with 6 blocks (replicates) and the following 3 experimental treatments:

1. Conventional tillage (CT)

2. No tillage (NT)

3. Minimum tillage (MT)

The area of each experimental unit was $300 \mathrm{~m}^{2}(15 \times 20 \mathrm{~m})$, with 10 and 5 meters of crossover spaces among blocks and among plots, respectively, to facilitate machinery operations.

Crop residues were chopped during wheat harvesting and soil incorporated in CT treatment; they remained as surface mulch in the NT treatment, ensuring a surface cover of about $70 \%$; finally, they were removed and only stubble were incorporated into the soil in MT treatment, because shallow tillage did not allow large amount of residues to be incorporated.

The CT treatment involved plowing (moldboard at 35-40 cm depth), two disc harrowing passes (15-20 cm depth) and a seedbed cultivator (Kongskilde Vibro) equipped with vibrating tines (Table S2). The MT treatment was performed with only one disc harrowing operation (15-20 cm depth). The NT treatment was performed with a no-till drill (Gaspardo Directa 300), drawn by a tractor of $132 \mathrm{KW}$ power and characterized by single-disk furrowers with a vertical coulter: in this way there is an effective tilling of the soil on the seed planting line favored, through the re-closing of the furrow, by the placing of loosened soil on the seed by means of a seed covering wheel. The drill was $3.0 \mathrm{~m}$ width and $0.20 \mathrm{~m}$ apart between rows and a seed depth of $5 \mathrm{~cm}$; no subsequent rulling operation was done. For this treatment, weeds were controlled with glyphosate [isopropylamine salt of $\mathrm{N}$-(phosphonomethyl) glycine] at a rate of $2 \mathrm{~L} \mathrm{ha}^{-1}$ few days before planting.

In CT and MT treatments the wheat sowing was performed using a mechanical row sowing machine, $4.0 \mathrm{~m}$ width, furrower $0.17 \mathrm{~m}$ apart and seed depth at $5 \mathrm{~cm}$.

\footnotetext{
* Further details about the Electronic Supplementary Material (ESM) can be found at the end of the article.
} 
Durum wheat (Triticum durum Desf.) cv. Chiara was sown on 3 January 2008 in the first year (a bit later than the usual local sowing time, 20 Nov-20 Dec) and on 10 December 2008 in the second year. Nitrogen $\left(90 \mathrm{~kg} \mathrm{~N} \mathrm{ha}^{-1}\right)$ was split, at the rate of $1 / 3$ before sowing (incorporated by disk harrowing in CT and MT and surface broadcast in NT) as diammonium phosphate (18:46:0), and 2/3 $\mathrm{N}$ top-dressed applied at the beginning of wheat tillering, corresponding to Stage 21 of the Zadoks scale (Zadoks 1974) as ammonium nitrate (34:0:0). During the growing season the weeds were controlled by means of specific herbicides: Tralcossidim (34.7\% a.i., $\left.1.7 \mathrm{~L} \mathrm{ha}^{-1}\right)+$ [Clopiralid (1.8\% a.i.) +2 -methyl-4-chlorophenoxyacetic acid (18.2\% a.i.) + Fluroxypyr (3.6\% a.i.) $\left.\left(2.0-2.5 \mathrm{~L} \mathrm{ha}^{-1}\right)\right]$ while no fungicide treatment was performed due to the absence of fungal diseases and insect attacks.

\section{Pre- and post-harvest measurements}

During the growing season at flowering stage (stage 61-65) on 9 May 2008 and 7 May 2009 , measurements of spectral reflectance in the 325-1075 nm wave length range were carried out with a portable HandHeld 2 Spectoradiometer of ASD Inc. (Colorado, USA): three shoots for each plot, and then averaged. The aims of these measurements were to evaluate the photosynthetic leaf activity using the vegetation indexes derived from measurements of light reflectance at specific wave lengths on wheat canopy surface (Table S3). The flowering stage was chosen for the positive correlation reported in literature between spectral index and future grain yield and grain protein content (Pettersson et al. 2006). Correlation analysis was carried out between spectral indexes and quantitative and qualitative traits, and this analysis was performed for each year separately.

Two-three weeks before wheat harvest, soil water content in each experimental unit was measured by means of gravimetric method in the $0-40 \mathrm{~cm}$ soil depth; soil moisture was expressed in volumetric basis $\left(\mathrm{m}^{3}\right.$ of water $\mathrm{m}^{-3}$ of soil) multiplying the values by soil bulk density $\left(1.15 \mathrm{t} \mathrm{m}^{-3}\right.$ ). Number of stems per square meter (stem density, SD) was evaluated choosing randomly an area of $1 \mathrm{~m}^{2}$ in each plot to count total number of stems.

Wheat was harvested early in June each year, using a $1.5-\mathrm{m}$ wide Wintersteiger plot combine $\left(4.5 \times 18 \mathrm{~m}=81 \mathrm{~m}^{2}\right.$ as sample $)$ and grain yield $\left(\mathrm{t} \mathrm{ha}^{-1}\right)$ was determined and expressed at $13 \%$ moisture content. For each plot at maturity two sub-samples $\left(1.0 \mathrm{~m}^{2} \mathrm{each}\right)$ were harvested to assess straw yield (SY), grain yield (GY), harvest index (HI). On each grain yield sample quality related traits were measured: Thousand-kernel weight (TKW, g) was calculated as the mean weight of three sets of 100 grains from each plot. Test weight (TW, $\mathrm{kg} \mathrm{hL}^{-1}$ ) was measured on a $250 \mathrm{~g}$ sample and expressed as $\mathrm{kg} \mathrm{hL}^{-1}$ obtained with a Shopper chondrometer equipped with a $1 \mathrm{~L}$ container. Grain nitrogen content was determined following the standard Kjeldhal method. Percentage of protein content (PC) was calculated after multiplying Kjeldhal nitrogen by 5.7 and was expressed on a dry weight basis. Yellow pigment index (b), evaluated using a chromameter (Konica Minolta, CR-400). Colour of wheat semolina was expressed using L* a* b* color system. $\mathrm{L}^{*}$ is a measure of brightness, $\mathrm{a}^{*}$ value is the red green coordinate while the $\mathrm{b}^{*}$ value is 
the blue yellow chromaticity coordinate. The rheological properties of dough prepared from semolina and water were evaluated using the Chopin Alveograph (Chopin, Cedex France) according to the standard method UNI 10453 (1995). The dough was formed into disc-shaped pieces that were inflated into bubbles. The pressure variation inside each bubble was recorded in graphical form as an 'alveogram' (Borghi et al. 1995). The maximum height of the curve provides an estimate of dough tenacity "P" denotes overpressure $(\mathrm{mm})$ and its length is a measure of dough extensibility " $\mathrm{L}$ " is the abscissa at rupture $(\mathrm{mm})$. "P/L" ratio indicates the value of dough elasticity. Finally, the area under the curve is proportional to the energy required to cause the test piece or dough bubble to break: "W", is the alveogram index $\left(10^{-4} \mathrm{~J}\right)$. Gluten content (GC, \%) and gluten index (GI) were measured by mean of Glutomatic 2200 instrument (Perten ${ }^{\mathrm{TM}}$ ) using the AACC method 38-12 (AACC 2000). Gluten index measures its force and can be considered medium from 46 to 65 , good from 66 to 85 and excellent above 85 up to 100 .

\section{Statistical analysis}

The data were subjected to analysis of variance, with the "Year" effect considered as a fixed effect. The means separation test was the Student-Newman-Keuls at 0.05 probability level. Correlation analysis (Pearson' coefficients) was performed among average values of wheat yield and quality traits as a function of vegetation indexes obtained with spectroradiometer. GLM and CORR procedure of SAS/STAT program were used in the analysis of variance, mean separation test and correlation analysis (SAS 2010).

\section{Results}

\section{Weather conditions}

The temperature followed the long-term averages, with only few periods that significantly differed from the average values. Mostly cold periods were parts of October 2007, February and April 2008. On the other hand, a particular hot period was recorded in May-June 2009, during the wheat grain filling.

About rainfall, with the exclusion of January-February 2008 period, when only $58 \mathrm{~mm}$ were measured, both experimental growing seasons were constantly rainier than longterm period. In fact, the total sum of rainfall from 1 October to 30 June were $479 \mathrm{~mm}$ in the first year and $540 \mathrm{~mm}$ in the second one, while the long-term average were $451 \mathrm{~mm}$.

Consequently, during these two years of experiment, the water supply was not the yield limiting factor. We have to consider, on the other hand, that large rainfall events occurred in 2008/09, like the December-February period, with more than $250 \mathrm{~mm}$ of rainfall in a period characterized by low evapotranspiration, low air temperatures and reduced wheat biomass. These large events could affect nitrogen availability especially after dress application (half of February). 


\section{Wheat grain yield and quality}

The statistical analysis (Table S4) shows as the interaction "Year $\times$ Tillage" resulted significant in 6 by 12 examined variables. Consequently, we will discuss "Year" main effect only for stem density, grain protein content, P/L, gluten index and gluten content; "Tillage" main effect for stem density, grain protein content, gluten index and gluten content. Harvest Index resulted not significant at all. For the interaction "Year $\times$ Tillage", all the remaining productive and qualitative variables (GY, SY, TW, TKW, YI and W) will be assessed and discussed.

Year effect. During the first year, with a more regular rainfall distribution, durum wheat was more productive than the second one (3.42 vs. $2.25 \mathrm{t}$ of grain ha ${ }^{-1}$ ). Despite of this, also grain quality related variables were better in the first than in the second year: TW (83.04 vs. $\left.73.15 \mathrm{~kg} \mathrm{hL}^{-1}\right)$, protein content (11.97 vs. 9.82\%) and yellow index (23.84 vs. $17.39 \%$ ). For these variables a comment about the significant "Year $\times$ Tillage" interaction will be discussed in the next section. The two experimental years showed significant differences for stem density and grain protein content (Table S4). The value of stem density at harvest higher in the 2009 than in 2008 ( 285 vs. 219 stems per $\mathrm{m}^{2}$ ), despite not resulted in higher yield, indicates a low grain yield per stem in the second year. In fact, all the qualitative parameters (except gluten index) were lower in the second than in the first year, nevertheless grain yield and grain quality are usually inversely correlated. Protein content (11.97 vs. $9.82 \%$, respectively, in the first and in the second year) was influenced in the second year by high temperature during grain filling and by the large rainfall (250 $\mathrm{mm}$ ) recorded during the winter season that, probably, leached soil mineral nitrogen below root depth and caused a deficiency during the final wheat growth stage. Protein content influenced also other two important parameters of quality in pasta production, $\mathrm{P} / \mathrm{L}$ and gluten content $(\%)$. Both parameters showed higher values and, consequently, a better quality of grain and semola, in the first than in the second year of experiment.

Tillage effect. The tillage resulted significant for almost all the productive and qualitative crop parameters. The grain yield resulted, on average in the 2-year period, higher in CT (3.29 $\left.\mathrm{t} \mathrm{ha}^{-1}\right)$ than in MT (2.67) and in NT (2.54). We will examine stem density, protein content, gluten index and gluten content that not resulted significant in the interaction with the Year (Table S4). Durum wheat sown with conventional tillage (CT) management produced a stems density at harvest significantly higher than in the no-tillage and minimum-tillage (MT and NT) (299 vs. 238 stems $\mathrm{m}^{-2},+25 \%$ ). This could be explained by a better soil preparation in $\mathrm{CT}$ and with seeds placed in optimal conditions to germinate, while in MT and NT a certain number of seeds can remain on soil surface. Grain protein content was significantly affected by Tillage treatments, it was higher in CT than in MT and NT management options (12.04 vs. $10.32 \%$ ) and this was observed in both years (Table S4). Similarly to protein content (gluten represents the largest protein component in wheat grains), also gluten content in CT was higher than in the other two tillage management of about $23 \%$. Finally, gluten index resulted lower in MT and not different in CT and NT. 
Year $\times$ Treatment interaction effect. Grain yield was very similar among the treatments in the first year of experiment $\left(\mathrm{CT}=3.55, \mathrm{MT}=3.51\right.$ and $\left.\mathrm{NT}=3.20 \mathrm{tha}^{-1}\right)$, while in the second year CT resulted higher if compared to the average of MT and NT of about $1.18 \mathrm{tha}^{-1}(+63 \%)$. This response must be evaluated considering the rainy conditions of both years and the fact that the experiment was carried out during the first two years of transition from CT to MT and NT management systems. Similar results were recorded for straw yield, with wheat in the CT that produced in both years about the same straw yield, while MT reduced significantly straw yield from the first to the second season $(-21 \%)$. Test weight resulted inversely correlated with grain yield, with no difference in the first year while in the second one NT was higher than the other two tillage treatments and MT was better than CT. Thousand-kernel weight index showed opposite behaviour in the two years. The lowest value in CT in the first year, the contrary in the second one. The semolina colour (yellow index) showed in the first year a substantial parity among soil tillage treatments, while in the second one, it was greater in CT than in NT and MT. Finally, W index, in the first year was significantly higher in CT than in the other two treatments, in the second year, MT resulted similar to the other two tillage management.

\section{Soil moisture}

The data about soil moisture (Fig. S1) indicated drier conditions in the first than in the second experimental year, for both less rainfall amount and larger plant water extraction by the soil (consequence of a larger grain yield in the $2^{\text {nd }}$ year). Among tillage treatments soil in CT was drier than in MT and NT, especially in the second year, according to the grain yield results.

\section{Vegetation indexes}

The compared vegetation indices showed significant correlations with productive and qualitative wheat characters. NDVI, the most widely used index, confirmed to be the most related index to crop greenness and, consequently, also to crop productivity. Figure S2 reported the most significant relationships $\left(\mathrm{R}^{2} \geq 0.5\right)$; for wheat grain yield, TVI and NDVI resulted in the highest correlation coefficients. TVI showed higher correlation coefficients values also with quality variables (test weight, protein content and W) than the other compared spectral indexes. From correlation analysis we observed inverse slopes of data between year and within year for test weight parameter. On the contrary, for grain yield, protein content and $\mathrm{W}$, also if with different values, the slopes of each year were always in agreement with the average slope of the two years.

In Fig. S3 the significant "Year $\times$ treatment" interactions of NDVI and TVI are reported. The highest levels of two indexes were obtained in the first year, showing a nitrogen availability greater in 2008 than in 2009. The differences among treatments were evident only in the second year, with a superiority of CT, lowest values in NT and intermediate in MT. This response can be explained by a different plant $\mathrm{N}$ availability in the two years, as previously observed for grain yield and protein content data. 


\section{Discussion}

Durum wheat sown with NT and MT tillage treatments, in climatic seasons characterized by enough rainfall during wheat crop cycle, as recorded in the two years of experiment, resulted less productive than $\mathrm{CT}$, at least for the examined grain yield and qualitative characters. This is in agreement with the results obtained in several environments (Kassam et al. 2012; Grigoras et al. 2012; Lithourgidis et al. 2011) that reported a reduction of grain yield ranging from 14 to $46 \%$ from CT to NT in rainy conditions.

In the semi-arid Mediterranean environments, the factor that most affects wheat productivity is soil water availability (Rinaldi 2004). Thus, the yield differences between NT and CT observed in the various trial conditions were related to the water availability. Many authors, similarly to our findings, showed that the superiority of NT respect to CT is evident only in winter wheat growing crop cycles with rainfall less than $300 \mathrm{~mm}$, thanks to more effective soil water storage in NT system (De Vita et al. 2007). LopezBellido et al. (1998) reported a significant positive effect of NT in drier years, on the contrary in the wetter ones: the rainfall threshold to separate wet from dry years is also function of soil water holding capacity: in Spanish conditions they found this threshold about $450 \mathrm{~mm}$.

On a long-term basis in the loess plateau of northern China, Li et al. (2007) reported that crop yield and water use efficiency tended to be higher under NT than under CT, especially in the years of low rainfall, suggesting that the change in soil structure has provided a better environment for crop development.

A clear grain yield difference have been found between soil tillage treatments only in the second year, characterized by a lower yield level than the first one. NT resulted less productive than CT\&MT in the first year, while CT was more productive than MT\&NT only in the second year $\left(+1.2 \mathrm{tha}^{-1}\right)$. This response can be explained by the large winter rainfall in the second year that could have a more negative impact in NT and MT; in addition, the rainfall could have leached a large amount of $\mathrm{N}$, producing a low $\mathrm{N}$ translocation from soil to grain, explaining also the protein and gluten content values lower in the second than the first year. The second year of experiment was unfavourable for grain wheat quality also for high temperatures recorded in the period $10^{\text {th }}$ May- $10^{\text {th }}$ June 2009 , when the maximum temperatures were $4.0^{\circ} \mathrm{C}$ on average higher than long-term values $\left(29.5\right.$ vs. $\left.24.5^{\circ} \mathrm{C}\right)$. This climatic behaviour produced a very fast plant senescence and short duration of flag leaf during a very critical period for grain filling and protein synthesis and translocation: this affected mainly TW $\left(83.04\right.$ vs. $73.15 \mathrm{~kg} \mathrm{hL}^{-1}$, respectively in the first and in the second year).

Another important result obtained in this research is about wheat quality and in particular the test weight, parameter of durum wheat grain quality that influences grain final market price. Test weight resulted significantly higher in MT $\left(78.6 \mathrm{~kg} \mathrm{hL}^{-1}\right)$ than in CT $\left(76.8 \mathrm{~kg} \mathrm{hL}^{-1}\right)$ and this is in agreement with Lopez-Bellido et al. (1998). On the contrary, the grain protein content was significantly higher in CT than in NT $(12.04 \%$ vs. $10.23 \%$, respectively). However, other studies have found that the tillage system has no effect on wheat grain protein content (Carr et al. 2003; Gürsoy et al. 2010). Rice et al. (1986) sug- 
gested that low availability of N frequently observed in NT soils can sometimes be a transient effect, as observed also in other long-term experiments (Amato et al. 2013; Ruisi et al. 2014). It has been suggested for these reasons a supplemental (10-20\%) N application in the NT systems during the conversion (2-3 years) period from CT to NT systems (Ferreira et al. 2009).

The main results of this study were that the effect of reduced tillage on grain yield depends very much on soil type, weather conditions, and time after conversion, whereas there is only minor impact on wheat quality.

Govaerts et al. (2005) and Hobbs (2007) suggest that NT planting may be considered a good agronomic practice because of its relatively lower production costs (due to savings in time and machinery use for tillage), but they also suggest the need for further research to verify the influence of relatively higher seeding rate on grain yield and quality of wheat. In fact, from the obtained results on stem density from our experiment, an increase of $15-20 \%$ on seed amount can be suggested in NT conditions, to ensure an optimal stem density that could compensate not germinated seeds because they were not completely covered by soil and remained on soil surface (Wiatrak et al. 2006; Amato et al. 2013).

The evaluation of a system to improve $\mathrm{N}$ application during growth cycle was carried out by means of spectral indices. Traditional indexes (i.e., NDVI and OSAVI) were poorly related with flag leaf $\mathrm{N}$ content. This inability was mainly due to sensitivity to LAI, which confounds predictions of crop $\mathrm{N}$ status, and thus limits the usefulness of spectral indices for predicting wheat $\mathrm{N}$ status under dryland conditions. By accounting for variability in LAI other indexes are more effective that use more chlorophyll content (MCARI, TCARI and TVI). The Triangular Vegetation Index has been reported as a good candidate for green LAI estimations, better than NDVI (Broge and Leblanc 2001; Haboudane et al. 2004). This has been confirmed by our results, of a higher correlation of TVI with quality variables (test weight, protein content and "W") than the other spectral indexes compared. The opposite response of test weight between and within years can be explained because it is very dependent by plant leaves activity and soil water availability in the grain filling period in durum wheat, while the spectral measurements in this research were carried out earlier, during flowering: this time shifting did not allow appreciating terminal stress among experimental treatments.

Our results confirmed as, in wet years and during the first years of conversion from conventional to conservative agriculture, NT and MT are less productive than CT (2.67 $\mathrm{t} \mathrm{ha}^{-1}$ of grain yield in MT and 2.54 in NT respect to $3.29 \mathrm{t} \mathrm{ha}^{-1}$ in CT). In this experiment, the positive effect of soil moisture higher in NT and MT than in CT was, therefore, not significant and effective for plant growth in wet conditions; further, other positive effects of NT and MT on soil quality did not emerge after only two years after the transition from conventional to conservative agriculture.

Another interesting result of this research was that the grain quality is more sensitive than grain yield to the "Year $\times$ Treatment" interaction, either for climatic variability or for cumulative effect of soil management on the same land. Therefore, in this work the "Year" effect was found to be the main source of variation for most of the analyzed parameters, the "Tillage" effect was also significant, although to a lesser extent; Test weight 
(important for final wheat grain price and for technological properties) resulted significantly higher in MT than in CT, but only in the second year $\left(73.72 \mathrm{vs} .71 .31 \mathrm{~kg} \mathrm{hL}^{-1}\right)$.

Finally, NDVI and TVI measurements at flowering stage, have been shown to be two spectral indexes well correlated with grain yield (both) and grain protein content (TVI), useful for suggesting N-late application to improve grain wheat quality. Supplemental seed amount at sowing and crop N fertilizer supply (especially in NT) should be considered during the conversion period to conservative agriculture systems, in order to stabilize grain yield and improve grain protein content.

\section{Acknowledgement}

The corresponding author wishes thank prof.ssa Giovanna Suzzi, coordinator of Doctorate School "Food Sciences" of University of Teramo (Italy).

\section{References}

AACC 2000. Approved Methods of the American Association of Cereal Chemists, 10th ed. St. Paul, USA. Amato, G., Ruisi, P., Frenda, A.S., Di Miceli, G., Saia, S., Plaia, A., Giambalvo, D. 2013. Long-term tillage and crop sequence effects on wheat grain yield and quality. Agron. J. 105:1317-1327.

Anken, T., Stamp, P., Richner, W., Walther, U., Weisskopf, P., Rek, J. 2006. Nitrate leaching and soil structural properties under conventionally cultivated and notill crops. In: Proc. 17th Conf. ISTRO. Kiel, Germany. pp. $1535-1540$.

Bhullar, S.S., Jenner, C.F. 1986. Effects of temperature on the conversion of sucrose to starch in the developing wheat endosperm grain physiology of wheat and barley. Aust. J. Plant Physiol. 13:605-615.

Borghi, B., Giordani, G., Corbellini, M., Vaccino, P., Guermandi, M., Toderi, G. 1995. Influence of crop rotation, manure and fertilizers on bread making quality of wheat (Triticum aestivum L.). Eur. J. Agron. 4:3745.

Broge, N.H., Leblanc, E. 2001. Comparing prediction power and stability of broadband and hyperspectral vegetation indices for estimation of green leaf area index and canopy chlorophyll density. Remote Sensing of Environment 76:156-172.

Brooks, A., Jenner, C.F., Aspinall, D. 1982. Effects of water deficit on endosperm starch granules and on grain physiology of wheat and barley. Aust. J. Plant Phys. 9:423-436.

Carr, P.M., Horsley, R.D., Poland, W.W. 2003. Tillage and seeding rate effects on wheat cultivars: I. Grain production. Crop Sci. 43:202-209.

Chen, J. 1996. Evaluation of vegetation indices and modified simple ratio for boreal applications. Can. J. Remote Sens. 22:229-242.

Colecchia S.A., Basso, B., Cammarano, D., Gallo, A., Mastrangelo, A.M., Pontieri, P., Del Giudice, L., Pignone, D., De Vita, P. 2012. On the relationship between N management and grain protein content in six durum wheat cultivars in Mediterranean environment. J. Plant Interactions 8:271-279.

Cox, D.J., Shelton, D.R. 1992. Genotype-by-tillage interactions in hard red winter wheat quality evaluation. Agron. J. 84:627-630.

Daughtry, C.S., Walthall, C.L., Kim, M.S., Brown de Colstoun, E., McMurtrey, J.E. 2000. Estimating corn leaf chlorophyll concentration from leaf and canopy refl ectance. Remote Sens. Environ. 74:229-239.

De Vita, P., Di Paolo, E., Fecondo, G., Di Fonzo, N., Pisante, M. 2007. No-tillage and conventional tillage effects on durum wheat yield, grain quality and soil moisture content in southern Italy. Soil Tillage Res. 92:69-78.

Di Fonzo, N., De Vita, P., Gallo, A., Fares, C., Padalino, O., Troccoli, A. 2001. Crop Management Efficiency as a Tool to Improve Durum Wheat Quality in Mediterranean Areas. Durum Wheat, Semolina and Pasta Quality, Montpellier (France), Ed. INRA, Paris (Les Coloques, no: 99). Paris, France. pp. 67-82. 
Erenstein, O. 2002. Crop residue mulching in tropical and semitropical countries: An evaluation of residue availability and other technological implications. Soil Till. Res. 67:115-133.

FAO 2011. What is conservation agriculture? FAO Conservation Agriculture Website at: http://www.fao.org/ ag/ca/1a.html.

Ferreira, A.O., Sà, J.C.M., Briedis, C., Figueiredo, A.G. 2009. Desempenho de genotipos de milho cultivados com diferentes quantidades de palha de aveia-preta e doses de nitrogenio (Corn genotype performance under black oat crop residues and nitrogen fertilization). Pesq. Agropec. Bras. 44:73-179. (in Portuguese)

Flagella, Z. 2006. Nutritional and technological quality of the durum wheat. Ital. J. Agron. 1(Suppl. 1):203239.

Govaerts, B., Sayre, K.D., Deckers, J. 2005. Stable high yields with zero tillage and permanent bed planting? Field Crops Res. 94:33-42.

Grigoras, M.A., Popescu, A., Pamfil, D., Has, I., Gidea, M. 2012. Influence of no-tillage agriculture system and fertilization on wheat yield and grain protein and gluten contents. J. Food, Agric. and Environ. 10:532-539.

Gürsoy, S., Sessiz, A., Malhi, S.S. 2010. Short-term effects of tillage and residue management following cotton on grain yield and quality of wheat. Field Crops Res. 119:260-268.

Haboudane, D., Miller, J.R., Tremblay, N., Zarco-Tejadad, P.J., Dextrazec, L. 2002. Integrated narrow-band vegetation indices for prediction of crop chlorophyll content for application to precision agriculture. Remote Sens. Environ. 81:416-426

Haboudane, D., Miller, J.R., Pattey, E., Zarco-Tejada, P.J., Strachan, I.B. 2004. Hyperspectral vegetation indices and novel algorithms for predicting green LAI of crop canopies: Modeling and validation in the context of precision agriculture. Remote Sens. Environ. 90:337-352.

Halloran, G.M. 1981. Cultivar differences in nitrogen translocation in wheat. Aust. J. Exp. Agric. 32:535-544.

Hemmat, A, Eskandari, I. 2006. Dryland winter wheat response to conservation tillage in a continuous cropping system in northwestern Iran. Soil and Tillage Res. 86:99-109.

Hobbs, P.R. 2007. Conservation agriculture: What is it and why is it important for future sustainable food production? J. Agric. Sci. 145:127-137.

Johnson, V.A., Mattern, P.J., Peterson, C.T., Kurh, S.L. 1985. Improvement of wheat protein by traditional breeding and genetic techniques. Cereal Chem. 62:350-355.

Kassam, A., Friedrich, T., Derpsch, R., Lahmar, R., Mrabet, R., Basch, G., González-Sánchez, E.J., Serraj, R. 2012. Conservation agriculture in the dry Mediterranean climate. Field Crops Res. 132:7-17.

Lampurlanés, J., Cantero-Martínez, C. 2006. Hydraulic conductivity, residue cover and soil surface roughness under different tillage systems in semiarid conditions. Soil and Tillage Res. 85:13-26.

Li, H.W., Gao, H.W., Wu, H.D., Li, W.Y., Wang, X.Y., He, J. 2007. Effects of 15 years of conservation tillage on soil structure and productivity of wheat cultivation in northern China. Aust. J. Soil Res. 45:344-350.

Lipiec J., Kuoe J., Slowinska-Jurkiewicz, A., Nosalewicz, A. 2006. Soil porosity and water infiltration as influenced by tillage methods. Soil Till. Res. 89:210-220.

Lithourgidis, A.S., Damalas, C.A., Eleftherohorinos, I.G. 2011. Conservation tillage: A promising perspective for sustainable agriculture in Greece. J. Sustainable Agric. 33:85-95.

Lopez-Bellido, L., Fuentes, M., Castillo, J.E., Lopez-Garrido, F.J. 1998. Effects of tillage, crop rotation and nitrogen fertilization on wheat-grain quality grown under rainfed Mediterranean conditions. Field Crops Res. 57:265-276.

Lopez-Bellido, L., Fuentes, M., Castillo, J.E., López-Garrido, F.J., Fernández, E.J. 1996. Long-term tillage, crop rotation, and nitrogen fertilizer effects on wheat yield under rainfed Mediterranean conditions. Agron. J. 88:783-791.

Lopez-Bellido, L., Lopez-Bellido, R.J., Castillo, J.E., Lopez-Bellido, F.J. 2001. Effects of long-term tillage, crop rotation and nitrogen fertilization on bread-making quality of hard red spring wheat. Field Crops Res. 72:197-210.

Lopez-Bellido, R.J., Lopez-Bellido, L. 2001. Efficiency of nitrogen in wheat under Mediterranean conditions: effect of tillage, crop rotation and $\mathrm{N}$ fertilization. Field Crops Res. 71:31-46.

McMaster, G.S., Palic, D.B., Dunn, G.H. 2002. Soil management alters seedling emergence and subsequent autumn growth and yield in dryland winter wheat-fallow systems in the central Great Plains on a clay loam soil. Soil Till. Res. 65:193-206. 
Micucci, F.G., Taboada, M.A. 2006. Soil physical properties and soybean (Glycine max Merrill) root abundance in conventionally- and zero-tilled soils in the humid Pampas of Argentina. Soil Till. Res. 86:152-162.

Mulla, D.J. 2013. Twenty-five years of remote sensing in precision agriculture: key advances and remaining knowledge gaps. Biosyst. Eng. 114:358-371.

Ozpinar, S. 2006. Effects of tillage on productivity of a winter wheat-vetch rotation under dryland Mediterranean conditions. Soil Till. Res. 89:258-265.

Pearman,, I., Thomas, S.M., Thorne, G.N. 1978. Effect of nitrogen fertilizer on growth and yield of semi-dwarf and tall varieties of winter wheat. Agron. J. 91:31-45.

Pettersson, C.G., Soderstrom, M., Eckersten, H. 2006. Canopy reflectance, thermal stress, and apparent soil electrical conductivity as predictors of within-field variability in grain yield and grain protein of malting barley. Precision Agric. 7:343-359.

Pringas, C., Koch, H.J. 2004. Effects of long term minimum tillage on yield and quality of winter wheat as affected by previous crop - results from 9 years of on-farm research. Pflanzenbauwissenschaften 8:24-33.

Randall, P.J., Moss, H.J. 1990. Some effects of temperature regime during grain filling on wheat quality. Austr. J. Agric. Res. 41:603-617.

Rao, S.C., Dao, T.H. 1996. Nitrogen placement and tillage effect on dry matter and nitrogen accumulation and redistribution in winter wheat. Agron. J. 88:365-371.

Rice, C.W., Smith, M.S., Blevins, R.L. 1986. Soil nitrogen availability after long-term continuous no-tillage and conventional tillage corn production. Soil Sci. Soc. Am. J. 50:1206-1210.

Rinaldi, M. 2004. Water availability at sowing and nitrogen management of durum wheat: a seasonal analysis with CERES-Wheat model. Field Crops Res. 89:27-37.

Rondeaux, G., Steven, M., Baret, F. 1996. Optimization of soil-adjusted vegetation indices. Remote Sens. Environ. 55:95-107.

Rouse, J.W., Haas, R.H., Jr., Schell, J.A., Deering, D.W., Harlan, J.C. 1974. Monitoring the vernal advancement and retrogradation (green wave effect) of natural vegetation. Type III final rep. NASA/GSFC, Greenbelt, MD, USA. 371 p.

Ruisi, P., Giambalvo, D., Saia, S., Di Miceli, G., Frenda, A.S., Plaia, A., Amato, G. 2014. Conservation tillage in a semiarid Mediterranean environment: results of 20 years of research. Italian J. of Agron. 9:560.

Sip, V., Vavera, R., Chrpova, J., Kusa, H., Ruzek, P. 2013. Winter wheat yield and quality related to tillage practice, input level and environmental conditions. Soil Till. Res. 132:77-85.

Six, J., Ogle, S.M., Breidt, F.J., Conant, R.T., Mosier, A.R., Paustian, K. 2004. The potential to mitigate global warming with no-tillage management is only realized when practiced in the long term. Glob. Change Biol. 10:155-160.

Stoddard, F.L., Marshall, D.R. 1990. Variability in grain protein in Australian hexaploids wheats. Austr. J. Agric. Res. 41:277-288.

Tebrügge, F., Düring, R.A. 1999. Reducing tillage intensity - a review of results from a long-term study in Germany. Soil Till. Res. 53:15-28.

Trethowan, R.M., Mahmood, T., Ali, Z., Oldach, K., Garcia, A.G. 2012. Breeding wheat cultivars better adapted to conservation agriculture. Field Crops Res. 132:76-83.

Troccoli, A., Borrelli, G.M., De Vita, P., Fares, C., Di Fonzo, N. 2000. Durum wheat quality: a multidisciplinary concept (mini review). J. Cereal Sci. 32:99-113.

UNI 1995. Methods: 10453 for Chopin Alveograph. Ente Nazionale Italiano di Unificazione. Milan, Italy.

Wiatrak, P.J., Wright, D.L., Marois, J.J. 2006. The impact of tillage and residual nitrogen on wheat. Soil Till. Res. 91:150-156.

Zadoks, J.C. 1974. A decimal code for the growing stages of cereals. Weed Res. 14:415-421. 


\section{Electronic Supplementary Material (ESM)}

Electronic Supplementary Material (ESM) associated with this article can be found at the website of CRC at http://www.akademiai.com/content/120427/

Electronic Supplementary Table S1. Main physical and chemical characteristics of soil

Electronic Supplementary Table S2. Description of main tillage operations of the three treatments in the two years of experiment

Electronic Supplementary Table S3. Equations used to calculate Vegetation Indexes from spectral measurements

Electronic Supplementary Table S4. Averages of the main productive and qualitative durum wheat traits and analysis of variance results

Electronic Supplementary Figure S1. Averages values of soil moisture (0-40 cm depth) before wheat harvest on $21^{\text {st }}$ May 2008 and $20^{\text {th }}$ May 2009

Electronic Supplementary Figure S2. Relationships by year of wheat characteristics and spectral indexes

Electronic Supplementary Figure S3. Averages values of significant "Year $\times$ Treatment" interaction for NDVI (Normalized Difference Vegetation Index) and TVI (Triangular Vegetation Index) recorded on durum wheat on $9^{\text {th }}$ May 2008 and 7 May 2009

$\mathrm{CT}=$ Conventional tillage $; \mathrm{MT}=$ Minimum tillage $; \mathrm{NT}=$ No Tillage 